\title{
2020 - The Lecturer at a Crossroads of Teaching and Learning in Academia in
} Israel

\section{Nitza Davidovitch ${ }^{1}$ Rivka Wadmany ${ }^{2}(\mathbb{D}$}

1.2 Ariel University, Israel.

Email:d.nitaa@ariel.ac.il

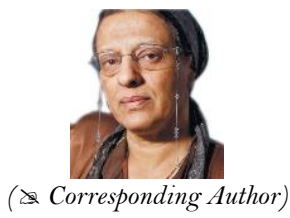

\begin{abstract}
The COVID-19 pandemic has created the greatest known disruption to the education system in Israel and in many countries around the globe, resulting in decisions to switch to online learning in all subjects. In the current study we examined lecturers' opinions on the advantages and disadvantages of online teaching from various aspects, from a systemic, multi-institutional perspective. The findings indicate that only about a third of the lecturers expressed a preference for online learning. The lecturers mentioned the lack of social and emotional interactions (SEL) between students and lecturers as one of the main disadvantages of online learning. In addition, most of the lecturers do not consider online learning as providing an advantage in the quality of teaching and learning. The study also indicates the need for perceptual changes among lecturers, so that they will reexamine the teaching and learning processes and adapt their role and responsibilities to the new opportunities enabled by today's technological tools and learning environments. The findings also indicate that the success of online learning requires appropriate pedagogical educational approaches rather than replication of traditional frontal teaching patterns on digital platforms. The findings call for in-depth discussion among higher education policymakers and academic institutions on the new and effective purpose of the campus in the post-covid period, the distinction between the virtual and the real in academic instruction, and the challenges and ways of coping with the new reality.
\end{abstract}

Keywords: Higher education, Online teaching, Online learning, Digital Pedagogy, Academia, Post- COVID period.

Citation | Nitza Davidovitch; Rivka Wadmany (2021). 2020 - The Lecturer at a Crossroads of Teaching and Learning in Academia in Israel. Journal of Education and e-Learning Research, 8(3): 281-289. History:

Received: 14 May 2021

Revised: 30 June 2021

Accepted: 21 July 202

Published: 17 August 2021

Licensed: This work is licensed under a Creative Commons

Licensed: This work is 1 ice
Attribution 3.0 License (cc) E

Publisher: Asian Online Journal Publishing Group
Acknowledgement: Both authors contributed to the conception and design of the study.

Funding: This study received no specific financial support.

Competing Interests: The authors declare that they have no conflict of interests.

Transparency: The authors confirm that the manuscript is an honest, accurate, and transparent account of the study was reported; that no vital features of the study have been omitted; and that any discrepancies from the study as planned have been explained.

Ethical: This study follows all ethical practices during writing.

\section{Contents}

1. Introduction

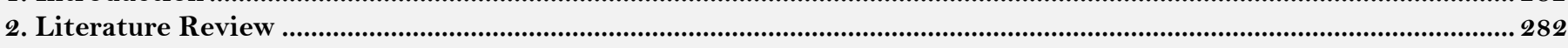

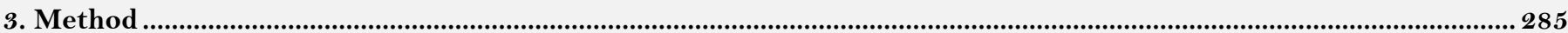

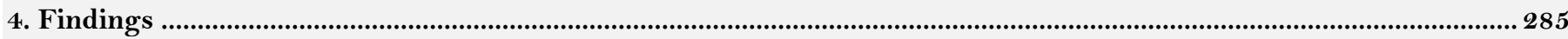

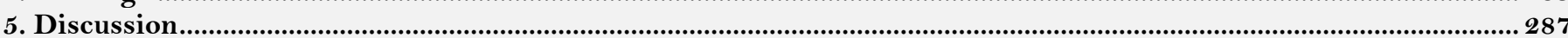

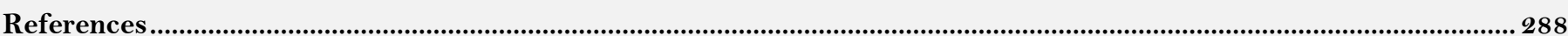




\section{Contribution of this paper to the literature}

This study contributes to existing literature by examining lecturers' opinions on the advantages and disadvantages of online teaching from various aspects, from a systemic, multi-institutional perspective.

\section{Introduction}

Academia has been offering online courses for years. Although diverse attempts have been made to promote this form of instruction in higher education in recent years, most teaching remains frontal - "face-to-face" teaching. The COVID-19 crisis has forced all of Israel's educational institutions to switch to online studies at record speed, without advance planning or preparations, in accordance with the directives of the Ministry of Health: The second semester of the 2020 school year at universities and colleges in Israel began with online learning, learning during a global crisis, with students being forced to stay home and complete their studies online in front of a computer monitor. Despite the constraints and lack of planning and advance preparations, faculty members at academic institutions of all types, who are typically evaluated almost exclusively on the basis of their published work, were forced to become creative and adopt new innovative approaches for teaching and evaluating their students, and apply them to optimally manage their courses.

The changes that have occurred in the educational system during this period form the basis for the inception of a new type of teaching, for productive thinking and for creative planning and development for faculty members and researchers. Universities and colleges are increasingly viewing online learning as an attractive way to leverage teaching and learning processes (Passey, 2019).

\section{Literature Review}

Online learning is characterized by learning anytime and anywhere. "Face-to-face" learning sessions in traditional learning spaces are replaced by technological devices such as smartphones, computers, apps and websites, online classes, recorded classes and presentations. The COVID-19 pandemic has increased the use of online learning in its diverse forms, along with efforts at their effective pedagogical use for the benefit of students at academic institutions whose learning experience was transformed by the health crisis. It should be noted that various academic institutions are gaining an appreciation of the economic and marketing potential of the use of these advanced technologies, since this type of learning creates a change in the teaching structure in academia (Davidovitch \& Eckhaus, 2020).

The research literature found that distance learning occurs when the teacher and students are separated by a physical distance and connected by technology. Remote open learning is defined as a teaching and learning process that is conducted, at least in part, online using text, audio and/or video (Allen \& Seaman, 2007; Passey, 2019). There are many and varied terms related to online learning, including asynchronous and synchronous learning, distance learning, computer-supported teaching, and other terms. The term e-learning pertains to three features:

1. The first pertains to the use of a communication network enabling storage, retrieval, distribution and updating in all disciplines.

2. The second pertains to information transmitted to users via computer and internet technology.

3. The third focuses on expanding learning solutions in order to improve performance (Anderson, 2008).

Hence, online learning is a learning experience that makes use of computers and the Internet, both on and off the premises of the educational organization. Teaching generally takes place in an online environment. Teaching activities take place online, with the teacher and learners being physically separated (in terms of place, time or both). The virtual classroom contains means of communication and workspaces that are defined by appropriate software. Features of traditional learning, such as conveying information and evaluating achievements through exams also take place in distance learning (Dabbagh \& Bannan-Ritland, 2005).

Goldschmidt (2013) distinguishes between unilateral technologies (written learning materials, video, TV and radio), and bi-lateral technologies (phone, email, online conference, Zoom, etc.). In his view, bi-lateral technologies enable students' interactions with the teacher and with other students. This interaction is the learner's ability to respond to the subject matter and to receive feedback on his comments from the teacher or other students, thus affecting the effectiveness of learning. The technology itself serves mainly as an infrastructure, and the choice of how to implement it is up to the developers and users. As a result, various models of online learning have been developed, ranging from replicating the well-known model of a lecturer delivering a frontal lecture without aids, through frontal lectures accompanied by a presentation, to innovative models combining a variety of content sources to offer new, participatory and less centralistic forms of learning. All of these can be conducted in a digital format available on the Internet for shared learning or viewing (Goldschmidt, 2013; Wadmany, 2018).

\subsection{Online Learning in Practice Put to the Test}

According to the research literature, online learning has diverse advantages.

First, online learning is considered less expensive compared to frontal learning. Online learning offers greater accessibility - students can learn using any device connected to the Internet, anywhere and at any time. In online environments, academic institutions are supposedly not required to make significant financial investments to budget for teaching staff, a library, and the operation and ongoing maintenance of classrooms and study spaces.

In addition, ongoing expenses for electricity, water and internet connectivity are significantly lower when lecturers and students remain at home and do not frequent the academic study space (Anderson, 2008; Wadmany, 2017; Wadmany, 2018). Since learning takes place outside the university, both teaching staff and students save the on transportation costs, along with many other expenses.

As for the content of lessons, in some cases the lecturer does not have to give physically teach the same lesson to different classes: The lecturer prepares the content once (recorded lessons, if the learning is asynchronous), and then shares it with different groups of students, not necessarily simultaneously (Dabbagh \& Bannan-Ritland, 2005; Davidovitch \& Eckhaus, 2020).

Online learning lets students learn at their own pace. Students can study the courses at anytime and anywhere, using a computer or smartphone, and can be mobile while studying (Barak, Dori, \& Hussein-Farraj, 2012). Students 
with families and jobs, who are usually busy with the chores of daily life, can study the recorded lessons when they have free time during the day. In addition, online learning is considered modern and advanced and suitable for the digital age. Most people today prefer to consume content through the internet rather than in other ways, such as reading the news, watching TV, conversing with friends, meetings, and shopping (Anderson, 2008; Dabbagh \& Bannan-Ritland, 2005). Therefore, in online learning, the study materials and learning speed can be adjusted to each learner according to their individual level, so that everyone progresses in the course at their own pace. Some note that a reduction in the teachers' workload, and an increase in learners' motivation, order and organization, and self-discipline have been observed (Dabbagh \& Bannan-Ritland, 2005; Miller \& Forkush-Baruch, 2018). We will present the challenges facing lecturers when it comes to teaching students.

\subsection{Adjustment}

The first difficulty is the adjustment challenge. The transition from traditional to computer-based learning in a virtual classroom completely changes students' learning experience, and can create resistance to such a change. The transition does not enable students and lecturers to adjust to the online learning environment easily, and it takes students and lecturers time to get used to online course management systems (CMS) and computer-based pedagogy. While learning in a traditional classroom is passive, online discussions or creating a web page requires action. Students and lecturers with a "traditional" mindset have difficulty adjusting but are forced to accept the new learning circumstances. Understanding the advantages of online learning and discussing them with lecturers and classmates may change this mindset and better prepare students for online classes (Bates \& Khasawneh, 2007; Palloff \& Pratt, 2007). Preparation on the part of the lecturers is important and essential, since they are in charge of running the course. Teaching centers in academia play a major role in this preparation as the professional-social frameworks that provide instruction and support to teachers (Davidovitch \& Eckhaus, 2020; Passey, 2019).

\subsection{Technical Issues and Internet Access during the COVID-19 Crisis}

According to data from the Central Bureau of Statistics for the year 2020, about 24\% of households with children in Israel do not have Internet access and $15.7 \%$ do not have a home computer. $21.7 \%$ of Jewish households do not have Internet, compared with about $51 \%$ of Arab households, and similar discrepancies were found in the context of home computer ownership. Therefore, when lecturers are required to teach online it is not clear how to accommodate various populations of students, including students who do not have access to the internet or other means required for this type of learning (Weissblau, 2020).

\subsection{Technological Operation}

Another difficulty stems from a lack of computer literacy. Although for the most part, students are experienced when it comes to technology, and are well-versed in the use of computers, lack of computer literacy is a key issue among students today. Many of them are unable to run basic programs such as Microsoft Word and PowerPoint and are therefore unable to handle their files. This is especially evident in exams, which students must upload their exams to the Moodle system. Technological skills are also necessary for students in order to use online courses to manage their assignments and their study software in an organized fashion. Basic computer literacy courses improve students' knowledge in the field. Basic familiarity with computer hardware will help them participate in online classes without interruptions and obstacles (Bates \& Khasawneh, 2007; Palloff \& Pratt, 2007). Students' ability to physically operate and use digital tools has a clear effect on the progression of the class session.

\subsection{Time Management and Planning}

Scheduling is a fundamental element of online learning, and it is important to schedule a time that will be devoted exclusively to studies. The lack of a fixed timeframe in a remote environment can make learning difficult. In addition, managing a learning process such as distance learning is different from face-to-face learning. The main difference is that because there are no time constraints or limitations, students have difficulty managing their learning activities efficiently and making effective use of the resources that the online environment offers. Time management is actually a difficult task for learners in online environments, since online courses require considerable time and intensive work. While most adults prefer Internet-based learning programs to study programs requiring their physical presence, since the former offer greater time flexibility, they rarely have the time and availability to take the courses due to their daily commitments. Setting a regular schedule will help these learners, since they can even set reminders for their courses and assignments (Bates \& Khasawneh, 2007; Herscovitz \& Kaberman, 2009).

\subsection{Learning Skills}

Other challenges are related to the need to read texts from a digital display (i.e., reading academic texts in digital format), which is complicated and exhausting for most learners, due to difficulty in navigation and the feeling that reading digital text is fatiguing. As a result, their achievements may be lower than those of students who read printed texts. Both teachers and students lack the cognitive skills that are necessary for effective and efficient use of online technologies. The lack of these skills can lead to misuse of these technologies for learning and teaching. For teachers, these skills include extracting information from graphic displays, building knowledge, assessing quality and creating meaningful learning materials from materials available in the online space (Bates \& Khasawneh, 2007).

Another matter is the pedagogical design, which is not adapted to online learning environments. In other words, online academic learning environments are perceived as complementary to lecture-based courses and therefore the pedagogical approaches are tailored to traditional classroom-based learning and teaching processes. As a result, in most cases, online courses are not tailored to pedagogical approaches for distance learning, which makes it difficult to acquire new learning skills (Palloff \& Pratt, 2007). 


\subsection{On Equality and Social Isolation}

One of the major challenges in the context of online learning during the crisis is equal opportunities among students. To this end, various countries have taken the following measure: distributing or lending end devices to needy students, offering Internet packages at discounted prices, offering the opportunity of receiving printed learning materials and more. UNESCO also emphasizes that students' isolation and the closure of traditional learning spaces intensifies the existing gaps and inequalities in the academic system and that students from disadvantaged populations are especially vulnerable to the effects of the crisis. This is because, in addition to the loss of learning opportunities, they are often denied access to meals offered in school and are subject to increased economic and social pressure (Weissblau, 2020). In addition, many students describe a feeling of loneliness and social disconnection when learning in the online environment. Students stress the lack of the physical reinforcements that are usually available in face-to-face learning. This sense of loneliness negatively impacted the students' academic achievements (Eshet-Alkalai \& Geri, 2007; Herscovitz \& Kaberman, 2009).

\subsection{Willpower and Self-Discipline}

Self-motivation is an essential requirement for learning in an online environment. However, many learners who study online lack motivation. It can be seen that after enrolling in distance learning courses, many students fall behind, fail to make progress, and cut corners (Song, Singleton, Hill, \& Koh, 2004). Both schoolchildren and college students must find the motivation to continuously keep up with the course and to properly equip themselves for the challenges that lie ahead. Only a positive attitude and motivation will help them overcome the challenges of online learning, and despite the challenges of adjusting to the transition, students must understand that adjustment is essential in order for them to reap the benefits of online learning in the future (Palloff \& Pratt, 2007).

In order to help students who have difficulty managing the remote learning process, the learning environment should be structured, organized, easy to navigate and user-friendly. All study materials must be accessible and presented in accordance with clear and pre-determined schedules. Assignments should promote active and meaningful learning, and should include interesting experiences related to the student's workplace, including opportunities for interaction with fellow students from different places in Israel and around the globe (Barak et al., 2012). A study by the Knesset Research and Information Center (Weissblau, 2020) found that many difficulties that arise as a result of the crisis and the grave implications of school closures and the transition to online learning for students and their families, including disruption of academic continuity and fear of an increase in dropout rates. Based on research findings and studies, it is evident that online learning is fraught with difficulties, along with its benefits. The hypotheses of the present study examine the connection between the difficulty of the transition to online learning and various aspects of online teaching, in light of studies carried out on the subject, reports of committees during the COVID-19 crisis, and data on online learning published by the Central Bureau of Statistics.

\subsection{Technology as an Effective Tool for Learning Skills Acquisition}

Active learning is a key factor in online learning because the lecturer is sometimes unavailable to assist the student, as is the case in face-to-face learning. Students must act independently on the basis of the various sources of information at their disposal (Berger-Tykocinski, Cohen, Haddad, \& Meni, 2020). Active learning has been found to be a factor that positively affects the satisfaction of students studying online, which also appears to contribute to their success in this learning method (Shain, cited in Berger-Tykocinski et al. (2020)).

Information literacy skills have also been mentioned as important skills for learners in any learning environment, and especially for online learners. These students, who rely heavily on digital resources in their learning, must develop broader and deeper information-finding skills compared to learners in a traditional setting (Berger-Tykocinski et al., 2020). Teachers can use various methods to develop information literacy among students such as the use of diverse materials from the Internet (such as video and audio clips), or ask learners to present their work on a digital platform (Takale, cited in Berger-Tykocinski et al. (2020)). Online learning requires lecturers to consider intelligent consumption of interactive online environments in order to promote meaningful learning (Ertmer \& Ottenbreit-Leftwich, 2010).

In their book, Meaningful Learning with Technology, Ashburn and Rivers (2006) stress that technology serves as an intellectual partner for learners that helps promote their thinking, learning, and understanding of the world we live in. Learning with technology will promote meaningful learning if it is based on learner involvement in knowledge building, discussions, independent articulation of acquired knowledge, and reflective thinking, and uses learning processes such as research, design, communication, writing, model-building, and visualization. Learning in a high-tech environment should be based on authentic research processes, knowledge building, and collaborative learning among learners.

Miodosur, Nachmias, and Forkosh-Baruch (2010) emphasize that a learning process combining technology is based on a variety of digital literacies, including multi-channel information processing literacy, cyberspace navigation literacy, communication literacy, visual literacy, hyper-literacy, personal information management literacy, and coping with complexity literacy. These literacies are part of the toolbox of the teacher and students, and their use may promote meaningful learning. To intelligently apply these literacies, it is important to rely on a pedagogy of SRL (Self-Regulation Learning) that emphasizes the learner's organization and regulation of learning through cognitive processes, meta-cognitive processes, and motivational processes. Learners set their learning goals, monitor and control their learning, while controlling their thought processes, motivation, and behavior. Therefore, the challenge faced by teachers and lecturers is to find the correct way to integrate technology and take advantage of the opportunities that it offers in an online space.

\subsection{Reducing Costs and Learning in Free Time}

The lack of the need for a physical campus and the associated costs of its operation when an online course taken by hundreds of thousands of students opens make it possible to reduce the costs of the academic courses taught online. However, developing lesson plans requires considerable resources, since they include photocopying 
material, collecting verbal and visual content, developing exams and other tasks. These tasks, however, do not have to be performed anew for each course (Allen \& Seaman, 2007; Goldschmidt, 2013).

In a state of emergency such as the COVID-19 crisis, which forced the closure of educational institutions, distance learning allows learners to maintain their academic continuity and reduces disruption to students' learning routines, while maintaining a supportive social-educational framework that also responds to emotional needs. In the case of synchronous learning, online learning allows learners to access the study materials either at their convenience or at pre-scheduled times, stay in touch with their classmates and lecturers, ask questions, take part in online class discussions and more (Weissblau, 2020).

\subsection{Adjustment Difficulties in the Transition to Online Learning}

Many students are liable to become confused and even indifferent due to the flexibility and freedom provided by online learning environments. Studies show that the ability to manage learning and course requirements in a flexible environment is the key to success in this type of learning. Therefore, the longer the courses last, the less likely learners are to properly manage their learning. The problem stems from several features of distance learning that may make it difficult for the learner, despite its advantages (Allen \& Seaman, 2007; Herscovitz \& Kaberman, 2009).

We are at a point in time that offers an opportunity for many studies on the topic of online teaching, for change and action in academic teaching, and for developing creative learning models. Therefore, the present study examines the effect of online teaching during a state of emergency in the higher education system in Israel on lecturers' opinions on the advantages and disadvantages of online teaching.

\section{Method}

This is a quantitative study based on an attitude survey conducted among lecturers at academic universities and colleges in Israel. The aim of the present study is to examine academic lecturers' perceptions of the advantages and disadvantages of various aspects of online teaching.

The survey questionnaire presented to participants several items on online learning's effects on the quality of teaching and learning as well as advantages and disadvantages. Participants were asked to rate their agreement on a scale from 1 (very strongly disagree) to 5 (very strongly agree). Table 1 presented presents the number of participants and the percentage of participants who strongly agreed and strongly disagreed with several items related to the various effects of online learning on the quality of teaching and learning.

\subsection{Research Questions}

1. What are the lecturers' personal, occupational, and academic profiles?

2. To what extent do lecturers express a preference for online teaching in general and toward specific types of classes in particular?

3. What are the lecturers' perceptions about the advantages and disadvantages of online learning?

4. What are the difficulties that arise in online teaching as perceived by the lecturers?

\subsection{Description of the Study Sample}

The study population comprised lecturers. The personal, family-occupational and academic backgrounds of the 223 lecturers are presented below: $51.0 \%$ are men and $49.0 \%$ are women; $62.2 \%$ hold the rank of lecturer, $19.6 \%$ the rank of teacher and $18.2 \%$ the rank of professor; $64.7 \%$ teach in social sciences and humanities and $35.3 \%$ teach exact sciences.

Table-1. Lecturers' Background Characteristics ( $\mathrm{N}=223$ ).

\begin{tabular}{|c|c|c|}
\hline \multirow[t]{3}{*}{$\overline{\text { Age }}$} & Range & $29-83$ \\
\hline & $\mathrm{M}$ & 52.30 \\
\hline & SD & 10.66 \\
\hline \multirow[t]{3}{*}{ Gender (\%) N } & Male & $(51.0 \%) 107$ \\
\hline & Female & $(49.0 \%) 103$ \\
\hline & Total & $100.0 \%$ \\
\hline \multirow[t]{4}{*}{ Academic rank (\%) $\mathrm{N}$} & Teacher & $(19.6 \%) 41$ \\
\hline & Lecturer & $(62.2 \%) 130$ \\
\hline & Professor & $(18.2 \%)$ \\
\hline & Total & $100.0 \%$ \\
\hline \multirow[t]{5}{*}{ Type of educational institution (\%) $\mathrm{N}$} & University & $(23.1 \%)$ \\
\hline & College of education & $(29.3 \%)$ \\
\hline & Academic college & $(38.1 \%)$ \\
\hline & Private college & $(9.5 \%)$ \\
\hline & Total & $100.0 \%$ \\
\hline \multirow[t]{3}{*}{ Discipline (\%) $\mathrm{N}$} & Humanities and social sciences & $(64.7 \%)$ \\
\hline & Exact sciences & $(35.3 \%)$ \\
\hline & Total & $100.0 \%$ \\
\hline
\end{tabular}

\section{Findings}

4.1. Preferences for Online Teaching

Table 2 presents lecturers' preferences for online teaching. 
Table-2. Personal Preference for Online Learning.

\begin{tabular}{|c|c|c|c|c|c|c|}
\hline & \multicolumn{4}{|c|}{ Degree of Preference $^{1}$} & \multirow[t]{2}{*}{$\bar{M}$} & \multirow[t]{2}{*}{ SD } \\
\hline & Low & Medium & High & Total & & \\
\hline Lecturers N (\%) & $57(25.6 \%)$ & $87(39.0 \%)$ & $79(35.4 \%)$ & $100 \%$ & 3.18 & 0.96 \\
\hline
\end{tabular}

Examination of the lecturers' degree of preference for online learning indicates polarization between them: The lectures have no unequivocal position on online learning: 35\% of the lecturers expressed strong willingness to teach online, versus $26 \%$, who expressed low willingness to teach online.

\subsection{Preference by Lesson Type}

The degree of preference for online learning is strongly related to the type of lesson being taught, as can be seen in Table 3.

Table-3. Preference for Teaching Different Types of Lessons Online.

\begin{tabular}{|c|c|c|c|c|c|c|c|c|}
\hline \multicolumn{4}{|c|}{$\begin{array}{l}\text { Percentage of lecturers who expressed high } \\
\text { willingness to teach the lesson online }\end{array}$} & \multicolumn{5}{|c|}{ Willingness to teach the lesson online } \\
\hline $\begin{array}{c}\text { Theoretical } \\
\text { lesson }\end{array}$ & $\begin{array}{c}\text { Tutorials for } \\
\text { theoretical } \\
\text { lesson }\end{array}$ & $\begin{array}{c}\text { Practical } \\
\text { lesson }\end{array}$ & Workshops & & $\begin{array}{c}\text { Theoretical } \\
\text { lesson }\end{array}$ & $\begin{array}{c}\text { Tutorial for } \\
\text { theoretical } \\
\text { lesson }\end{array}$ & $\begin{array}{c}\text { Practical } \\
\text { lesson }\end{array}$ & Workshops \\
\hline \multirow[t]{2}{*}{$69.3 \%$} & \multirow[t]{2}{*}{$42.1 \%$} & \multirow[t]{2}{*}{$14.0 \%$} & \multirow[t]{2}{*}{$19.5 \%$} & $\mathrm{M}$ & 3.95 & 3.13 & 2.00 & 2.26 \\
\hline & & & & SD & 1.12 & 1.38 & 1.24 & 1.34 \\
\hline
\end{tabular}

All the lecturers expressed high willingness to learn/teach theoretical lessons online, but their willingness to learn practical lessons or workshops online is low. Preference rates for teaching theoretical lessons online are high (69\% of lecturers), and higher than the preference rates for teaching a tutorial online (42\%). The preference rates for teaching practical lessons online are very low (14\%). Finally, low preference rates were also found for teaching workshops online (19\%). Table 4 presents the lecturers' perceptions regarding online teaching.

\begin{tabular}{|c|c|c|c|c|c|c|}
\hline & \multicolumn{4}{|c|}{ Ratings } & \multirow[t]{2}{*}{$\mathbf{M}$} & \multirow[t]{2}{*}{ SD } \\
\hline & Low & Moderate & High & Total & & \\
\hline Lack of interpersonal interaction & $\begin{array}{c}13.4 \% \\
(\mathrm{n}=29)\end{array}$ & $\begin{array}{c}20.7 \% \\
(\mathrm{n}=45)\end{array}$ & $\begin{array}{c}65.9 \% \\
(\mathrm{n}=143)\end{array}$ & $100 \%$ & 4.36 & 0.63 \\
\hline Order, organization and clarity in teaching & $\begin{array}{c}42.6 \% \\
(\mathrm{n}=92)\end{array}$ & $\begin{array}{c}37.5 \% \\
(\mathrm{n}=81)\end{array}$ & $\begin{array}{c}19.9 \% \\
(\mathrm{n}=43)\end{array}$ & $100 \%$ & 2.80 & 0.89 \\
\hline Cost-effective for students & $\begin{array}{c}45.0 \% \\
(n=100)\end{array}$ & $\begin{array}{c}39.2 \% \\
(\mathrm{n}=87)\end{array}$ & $\begin{array}{c}15.8 \% \\
(\mathrm{n}=35)\end{array}$ & $100 \%$ & 2.71 & 0.77 \\
\hline
\end{tabular}

Table 4 shows that lecturers hold negative opinions about this type of teaching: two-thirds of the lecturers are dissatisfied with the fact that online learning reduces the interpersonal interaction between them and the students and among themselves.

In addition, only about one-fifth of the lecturers believe that the quality of online teaching is higher quality than the quality of regular teaching, and here too lecturers had more negative perceptions of online teaching compared to students. Only one-sixth of the lecturers believe that online learning is cost-effective for student in terms of their ability to cope with the learning process and the subject matter, or to benefit from the class.

\subsection{Factors Influencing Lecturers' Preference for Online Learning}

We calculated two models that attempt to predict lecturers' preferences for online teaching. The first model included only variables related to teaching itself (e.g., order, organization and clarity, and lack of personal interaction). The following is the first linear regression model:

Table-5. Linear Regression Coefficients among Lecturers - Model 1 - Predicting Perceptions of Online Learning.

\begin{tabular}{l|c|c|c}
\hline & B & $\boldsymbol{\beta}$ & $\mathbf{T}$ \\
\hline Constant & 2.14 & & $5.94^{* *}$ \\
\hline Order, organization and clarity in teaching & 0.39 & 0.37 & $4.99^{* *}$ \\
\hline Lack of interpersonal interaction & -0.24 & -0.25 & $-4.59^{* *}$ \\
\hline Feasibility for students & 0.32 & 0.25 & $3.18^{* *}$ \\
\hline Note: ${ }^{* *} p<.01,{ }^{*} p<.05$.
\end{tabular}

Model 1 is significant $(F(3,212)=111.05, p<.01)$ and explains $61 \%$ of the variance between faculty members' preferences for online learning $\left(\mathrm{r}^{2}=.611\right)$. The findings indicate that all three variables related are clear predictors of preferences for online teaching, but the variable order, organization and clarity in teaching has greater predictive power than the remaining two variables.

Sub-model A of the second regression model that was calculated examines the effect of background variables on preferences for online teaching (e.g., the importance of teaching ratings, current teaching rating, institution type [university vs. college], discipline [exact sciences vs. humanities and social sciences], lecturer's self-evaluation, age, gender, academic rank). Sub-model B includes all of the above variables as well as the online learning ${ }^{1}$ The variables were grouped so that variable values between 1 and 2.5 indicate low preference for online learning, values between 2.51 and 3.5 indicate a
moderate preference, and values above 3.51 indicate a high preference for online learning. All variable distributions in the study were classified using this method. 
perception metrics. Table 6 presents the regression model characteristics in the first and second stages of the overall model.

Table-6. Model 2 - Background Variables and Perceptions of Online Learning.

\begin{tabular}{|c|c|c|}
\hline & $\mathbf{F}$ & $\mathbf{r}^{2}$ \\
\hline Sub-model A - Predictors: Background variables & $6.10^{* * *}$ & 0.32 \\
\hline Sub-model B - Predictors: Background variables and perception of the online environment & $18.18^{* * *}$ & 0.67 \\
\hline
\end{tabular}

It can be seen that both sub-models are statistically significant, and the sub-model that includes only background variables explains about one-third of the variance in faculty members' in preferences for online teaching, while the full model explains about two-thirds of the variance in preferences. Table 7 presents the regression coefficients of the Sub-model A, which includes only background variables as predictors.

\begin{tabular}{l|c|c|c}
\multicolumn{4}{c}{ Table-7. Model 2 Sub-model A - Background Variable Predictors. } \\
\hline Constant & $\mathbf{B}$ & $\boldsymbol{\beta}$ & $\mathbf{t}$ \\
\hline Importance of teaching review ratings & 5.74 & & $7.45^{* *}$ \\
\hline Age & -0.38 & -0.53 & $-6.52^{* *}$ \\
\hline Gender & -0.01 & -0.13 & -1.53 \\
\hline Average teaching review score & -0.22 & -0.12 & -1.35 \\
\hline Self-evaluation as lecturer & -0.20 & -0.10 & -1.06 \\
\hline Academic rank & -0.09 & -0.06 & -0.65 \\
\hline Department & 0.17 & 0.05 & 0.64 \\
\hline Academic institution type & -0.10 & -0.05 & -0.61 \\
\hline Note: ${ }^{*}<0.01, *<0.05$. & 0.10 & 0.04 & 0.53 \\
\hline
\end{tabular}

These findings suggest that the only background variable that explains lecturers' preferences for online learning is their concern with regard to a potential drop in the feedback scores they receive following the transition to online teaching.

Table 8 presents the regression coefficients for Model 2, which includes background variable predictors and metrics of the perception of online learning. The perceived lack of interpersonal interaction has the greatest (negative) effect on lecturers' preferences for online learning, and the two variables related to learning have a strong effect on lecturer's willingness: the cost-effectiveness of online learning for students, and order and organization and clarity in teaching.

\begin{tabular}{l|c|c|c} 
Table- 8. Model 2 Sub-model B (Full Model) - Background Variables and Online Learning Perception Metrics. \\
\hline & $\mathbf{B}$ & $\boldsymbol{\beta}$ & $\mathbf{t}$ \\
\hline Constant & 4.33 & & $6.28^{* *}$ \\
\hline Lack of interpersonal interaction & -0.28 & -0.30 & $-4.12^{* *}$ \\
\hline Cost-effectiveness for students & 0.33 & 0.27 & $2.50^{*}$ \\
\hline Order, organization and clarity in teaching & 0.27 & 0.26 & $2.47^{*}$ \\
\hline Age & -0.01 & -0.17 & $-2.83^{* *}$ \\
\hline Importance of the teaching review rating & -0.11 & -0.15 & $-2.26^{*}$ \\
\hline Self-evaluation as a lecturer & -0.14 & -0.09 & -1.34 \\
\hline Gender & -0.16 & -0.08 & -1.38 \\
\hline Academic institution type & 0.11 & 0.05 & 0.79 \\
\hline Discipline & 0.06 & 0.03 & 0.53 \\
\hline Average teaching review score & 0.05 & 0.02 & 0.38 \\
\hline Academic rank & -0.03 & -0.01 & -0.19 \\
\hline
\end{tabular}

Academic rank

Note: ${ }^{*} p<.01,{ }^{*} p<.05$.

Two background variables that have a more limited effect on preferences but are statistically significant are also worthy of attention: age (preferences for online learning decreases as the lecturer's age increases), and concerns that the transition to online learning will adversely affect the lecturer's teaching reviews.

\section{Discussion}

The COVID-19 pandemic found Israel's higher education system unprepared. In this time of emergency, online learning constituted a solution, with the alternative being to shut down the entire school system (Altbach \& De Wit, 2020) Measures of success and quality of teaching during emergencies and during routine periods are different. In contrast to routine periods, during the emergency lecturers were less expected to keep up with the ordinary pace of teaching the materials on schedule, on the understanding that the emergency might soon be over and it would be possible to make up lost material.

The current study examined the lecturers' perceptions of the advantages and disadvantages of online teaching from various aspects, from a systemic, multi-institutional perspective. Study participants were lecturers who teach at various types of academic institutions: universities, academic colleges of education, academic colleges of engineering and private colleges.

Findings indicate that the lecturers believe that online learning/teaching is not equally suitable for all types of lessons and is mostly suitable for theoretical lessons. Few believe that workshops, practical lesson, and hands-on experience can be conducted online. An example of this is teaching training: at present, while Israeli schoolchildren learn online from home, teaching and education students also continue their curriculum through online learning, and these students do their practice teaching online. Some participants believe that this will delay the training process of the future teachers of the Israeli education system. Conversely, other participants who think that online 
teacher training is an opportunity to train the teachers of tomorrow who will know how to function in a dynamic world of frequent change (Ran, 2020). The transition to distance teaching, especially online teaching, creates new opportunities for students to work in teams and to provide personal attention to students who did not receive the attention they needed in ordinary classroom situations due to class size or other reasons (Balas, 2020).

The lecturers also mentioned the lack of personal interaction and social and emotional learning (SEL) between students and lecturers as one of the main disadvantages of online learning/teaching. These findings correspond with the model developed by Salmon (2019) who argues that at the beginning of every online course, after the technical difficulties have been resolved, learners' socialization should be developed, learners should be encouraged to text one another and establish their online identity. This step is essential for the subsequent effectiveness of teaching and learning online.

The study highlights the role of the lecturer in the digital age, the practice of teaching, and specifically the role of the professionals in charge of the pedagogical aspects of teaching and learning at academic institutions. The findings of the study indicate that the new pedagogical world is committed to setting itself new goals and reconstructing a new profile for teachers as digital pedagogues. Digital pedagogues must understand the new opportunities inherent in the technological world for designing learning environments that will cope with increasingly diverse and ethical tasks (Benade, 2017; Wadmany, 2018).

The majority of research on information and communications technology and online learning focuses on the number of courses taught, the number of participating students participating, and success of online teaching. They rarely address the potential that e-learning offers to upgrade teaching and learning, and use online means to improve various pedagogical issues, such as: interaction between faculty and students, course content and teaching methods.

Recognizing the COVID-19 era as an opportunity to rethink teaching practices that may lead to a paradigm shift, it is vital to embark on a mission of exploration to adopt new pedagogies that are uniquely suited to the new technologies. To improve lecturers' teaching skills and abilities, the pedagogical aspects of the use of new technological tools must be strengthened. New programs should be developed to guide the adoption of the new digital tools as an integral part of teaching practice and not as an external aid that merely supplements teaching and learning.

The COVID-19 crisis is, thus, a great opportunity to accelerate awareness and action in academia. This is a propitious time, a genuine window of opportunity has now opened for change and transition from a conservative academic system to an innovative, proactive, learning-based system. In effect, it is an opportunity for the rapid assimilation of technology, innovative pedagogy and advanced management systems. The COVID-19 crisis has demonstrated that the higher education system and its leaders have the capability and the resilience to function in times of crisis. The digital learning that was forced on the academic system overnight thrust the institutions' leaders, lecturers and students to the forefront of the stage, into a completely different routine. Within the span of several weeks, classrooms were abandoned, digital arenas were established, content was developed, and dedicated teaching workshops were conducted. This was a time of accelerated use of online technology and a place for independence, creativity, and entrepreneurship, with potential for further evolvement and development. This period also clarified that online learning cannot be a "copy-paste" of frontal learning techniques to online platforms: It requires a distinct pedagogy. We must therefore rethink the content, pedagogy, learning methods and evaluation methods. There is a major gap in the learning skills acquired in a traditional classroom versus a virtual classroom, and this gap must be reduced.

The academic education system has proven that alongside the numerous difficulties created by the crisis, distance learning also offers benefits, such as such as learning at any time and from anywhere, and the possibility of planning, streamlining and adapting courses and learning methods to students. However, the findings of the study prove that there is no substitute for personal contact and interactions between teachers and students and among the students themselves. Online learning is a unique and powerful solution but not to be used exclusively, and certainly not for all disciplines and teaching methods. It appears that combining online learning with frontal learning has the potential to improve students' learning experiences, success, and achievements. Advance preparation may help equip lecturers and students, in a gradual and structured manner, for the challenging task of teaching and learning in the future.

\section{References}

Allen, I. E., \& Seaman, J. (2007). Online nation: Five years of growth in online learning. Newburyport, MA: Sloan Consortium.

Altbach, G. P. G., \& De Wit, H. (2020). Are we at a transformative moment for online learning? Retrieved from: https://www.forbes.com/sites/andrewdepietro/2020/04/30/impact-coronavirus-covid-19-collegesuniversities/\#1867f57d61a6.

Anderson, T. (2008). The theory and practice of online learning (2nd ed.): A thabasca University Press.

Ashburn, F. A., \& Rivers, E. R. (2006). Meaningful learning using technology: What educators need to know and do: Teachers College Press.

Balas, N. (2020). Opportunities and risks in the education system in the wake of the Covid-19 crisis: Overview. In: State of the Nation Report 2020. Jerusalem: Taub Center for Social Policy Studies in Israel.

Barak, M., Dori, Y., \& Hussein-Farraj, R. (2012). Lifelong learning at the Technion: Graduate students' perceptions of and experiences in distance learning. In Y. Eshet-Alkalei, A. Caspi, S. Eden, N. Geri, Y. Yair, and Y. Kalman (Eds.). Paper presented at the Learning in the Technological Era: Proceedings of the Chais Conference for the Study of Innovation and Learning Technologies. Open University.

Bates, R., \& Khasawneh, S. (2007). Self-efficacy and college students' perceptions and use of online learning systems. Computers in Human Behavior, 23(1), 175-191.

Benade, L. (2017). Being a teacher in the 21 st century: Springer.

Berger-Tykocinski, T., Cohen, A., Haddad, N., \& Meni, I. E. (2020). Skills for effective online learning in the age of Corona and beyond: The Henrietta Szold Institute.

Dabbagh, N., \& Bannan-Ritland, B. (2005). Online learning: Concepts, strategies, and application. Upper Saddle River, NJ: Pearson/Merrill/Prentice Hall.

Davidovitch, N., \& Eckhaus, E. (2020). Exploring the true motivation of faculty members to promote technological innovation in their courses. In $S$. Nazir, T. Ahram and W. Karwowski (Eds.). Paper presented at the Advances in Human Factors in Training, Education, and Learning Sciences, Proceedings of the AHFE 2020 Virtual Conference on Human Factors in Training, Education, and Learning Sciences July 16-20, 2020. Springer.

Ertmer, P. A., \& Ottenbreit-Leftwich, A. T. (2010). Teacher technology change: How knowledge, confidence, beliefs, and culture intersect. Journal of research on Technology in Education, 42(3), 255-284. Available at: https://doi.org/10.1080/15391523.2010.10782551. 
Eshet-Alkalai, Y., \& Geri, N. (2007). Does the medium affect the message? The influence of text representation format on critical thinking. Human Systems Management, 26(4), 269-279.

Goldschmidt, R. (2013). Online academic learning and the recognition thereof. The Knesset - Research and Information Center. Retrieved from: https://m.knesset.gov.il/Activity/Info/MMM/Pages/document.aspx?docId=CAS-56772-R8B5Co.

Herscovitz, O., \& Kaberman, Z. (2009). Teachers' preparation and professional development via distance teaching and learning as a way of coping with lack of teachers. Haifa: Technion, Israel Institute of Technology. Department of Technology and Science Teaching.

Miller, N., \& Forkush-Baruch, A. (2018). The use of online teaching in the subject of Hebrew language skills among high school students taking the 11th grade matriculation exam. In $Y$. Eshet-Alkalay et al. (Eds.). Paper presented at the Learning in the Technological Era: Proceedings of the 13th Chais Conference for the Study of Innovation and Learning Technologies. The Open University.

Miodosur, D., Nachmias, R., \& Forkosh-Baruch, A. (2010). New literacies for the knowledge society. Paper presented at the Eureka, Tel Aviv Science, National Teachers Center for Science and Technology, The Center for Science and Technology Education, Tel Aviv University.

Palloff, R. M., \& Pratt, K. (2007). Building online learning communities: Effective strategies for the virtual classroom (2nd ed.): John Wiley \& Sons.

Passey, D. (2019). Technology-enhanced learning: Rethinking the term, the concept and its theoretical background. British Journal of Educational Technology, 5O(3), 972-986. Available at: https://doi.org/10.1111/bjet.12783.

Ran, A. (2020). Distance learning in the days of COVID-19: An opportunity for systemic change. Calcalist, August 22. Retrieved from: https://www.calcalist.co.il/local/articles/0,7340,L-3802910,00.html.

Salmon, G. (2019). E-moderating: The key to online teaching and learning: Routledge.

Song, L., Singleton, E. S., Hill, J. R., \& Koh, M. H. (2004). Improving online learning: Student perceptions of useful and challenging characteristics. The Internet and Higher Education, 7(1), 59-70. Available at: https://doi.org/10.1016/j.iheduc.2003.11.003.

Wadmany, R. (2017). Digital pedagogy - from theory to practice: Mofet, Kibbutzim College. [Hebrew].

Wadmany, R. (2018). Digital pedagogy - Opportunities for different learning: T Mofet, Kibbutzim College.

Weissblau, E. (2020). Emergency distance learning during the closure of educational institutions in the wake of the outbreak of Covid-19: The Knesset - Research and Information Center. Retrieved from: https://main.knesset.gov.il/activity/info/mmm/pages/document.aspx?docid=6c81656c-de69-ea 1 1-81 13-00155doaf32a. 